\title{
Exploration and Practice of the "Studio System" Teaching Model for the Visual Communication Major in Local Colleges and Universities
}

\author{
Jing $\mathrm{Hou}^{1, *}$ \\ ${ }^{1}$ Zaozhuang University, Zaozhuang, Shandong 277160, China \\ *Corresponding author. Email: 37013844@qq.com

\begin{abstract}
With the increasing demand of society for the quantity and quality of visual communication professionals, the teaching organization form should be reconstructed and the teaching organization process should be optimized on the basis of the traditional talent training program so as to improve the teaching level and the quality of talent training through constructing a "studio system" teaching model. The article takes the visual communication major of local colleges and universities as the research object, firstly expounds the "studio system" and its characteristics and then explores the typical teaching model of the "studio system" of the visual communication major, and finally, alternative practical paths are given in terms of element organization and formation, construction of practical teaching system, as well as introduction and distribution of practical training projects.
\end{abstract}

Keywords: Visual communication major, Studio system, Teaching model, Local colleges and universities, Exploration and practice.

\section{INTRODUCTION}

The "studio system" was born at the Staatliches Bauhaus in Germany a century ago, which grew out of the "workshop system", with its core concept placing equal emphasis on art and technology, and theory and practice. In the past 100 years, design education around the world has carried out such teaching experiments and achieved excellent results, such as the "Teaching Factory" of Nanyang Polytechnic and the "Texas Rangers" design laboratory in Texas, USA [1]. In the teaching practice of relevant majors in these colleges and universities, although the application of the "studio system" has its own characteristics, they all use "specific design projects" as the "center of a circle" to integrate theoretical basic courses and professional practice, with the purpose of allowing students to build their own knowledge structure in the hands-on experience and to lay the foundation for the acquisition and improvement of comprehensive innovation capabilities. In China, applying the "studio system" teaching model to the cultivation of professionals in visual communication can break through the original knowledge barriers between courses and majors, use comprehensive and cross-cutting project design to guide and help to connect and combine fragments and even fragmented knowledge theories, and guide students to complete the absorption of explicit knowledge and the sharing of tacit knowledge through situational demonstration guidance, team interaction, etc. In this way, it can not only allow the training of visual communication professionals to dock with the society and improve students' professional skills and market awareness, but also shorten the job adaptation period, which can be of great help in enhancing the effect of school-enterprise cooperation and promoting the healthy and rapid development of local colleges and universities. Next, the article discusses the exploration and practice of the "studio system" teaching model for the visual communication major in local colleges and universities, hoping to provide useful information for the training and professional development of professionals. 


\section{THE "STUDIO SYSTEM" TEACHING MODE AND ITS CHARACTERISTICS}

For applied colleges, especially applied design colleges, the "studio system" teaching model can promote the cooperation of "production, study, and research", help the construction of the "doublequalified" teacher troop, and can also enhance the social influence of design major and improve the reputation of running schools. And the reason for this is that the teaching model meets the demands of talent training in the new era and helps to improve the comprehensive ability and comprehensive quality of professionals. It is generally believed that the "studio system" teaching model has realized the reform of the traditional curriculum and teaching mode, realized the close integration of teaching and production by emphasizing the principle of being "studentoriented, knowledge-based, technology-centered, and practical training-aided", and promoted the deep integration of curriculum, classroom and practice. It is an open teaching model oriented to actual production.

\subsection{Introduction to the "Studio System" Teaching Model}

According to experience, the "studio" can not only improve the quality of running a school, cultivate more talents who adapt to social development and meet the needs of the times, but also relieve employment pressure, so that students, teachers, and schools can all benefit from it [2]. Therefore, constructing and perfecting the "studio system" teaching model is an important option for the teaching and talent training of applied subjects including the "visual communication major". The "studio system" teaching model is a new and effective model in teaching reform, which is regarded as an important direction and future trend of reform by many professional courses. Although the "studio system" teaching practice is still in the introduction phase in China, the development in recent years has shown that more and more schools in China are actively constructing a "studio system" teaching model in line with national conditions, hoping to meet the needs of professional development and industrial development. Generally speaking, the "studio" belongs to the "exploratory classroom" and also the "practice site" for the development of teaching courses. In this way, it can enable students to acquire knowledge theory, improve professional skills, and fully implement specific professional curriculum content under the concept of combining industry with education.

\subsection{Characteristics of the "Studio System" Teaching Model}

The "studio system" is a new type of teaching model. Although it has been a century since its emergence, it has remained vibrant in its effective integration with the market and is of great relevance in developing students' practical skills and developing their awareness of thinking [3]. This model is mostly used in majors with certain development potential, and with the economic and social development and technological progress, it has gradually developed into other fields with the characteristics of strong competition mechanism, flexible and diverse teaching methods and teaching means, and more comprehensive curriculum structure system. Students can choose studios according to their individual preferences. The curriculum provision is more scientific, and the basic knowledge and practice are more closely integrated.

\section{THE TYPICAL MODEL OF "STUDIO SYSTEM" TEACHING IN THE VISUAL COMMUNICATION MAJOR}

In China, the major of visual communication focuses on the fields such as corporate product packaging, and it also carries out visual design work for inner-enterprise goods or logos [4]. In this way, the distance between enterprises and consumers can be significantly shortened, which is of great benefit to improving product quality, service level and market reputation [5]. Therefore, the professional teaching work must be based on traditional knowledge instillation, focusing on students' application and practice of knowledge theory. "Studio system" is a "key option". From a macro perspective, the "studio system" of the visual communication major can not only classify and reorganize the original teaching resources so as to emphasize the professional quality and market application ability of students, but also cultivate students' innovative thinking and practical ability, so that students can discover their own problems and correct them in time with a strong sense of experience and participation. Combined with the talent training experience of the visual communication major, the "studio system" teaching model mainly includes the following types: 


\subsection{Project Studio}

The project studio of the visual communication major is hosted and run by professional teachers. The project content, teaching materials and key knowledge of the studio are fully integrated by the teachers. During this period, teachers will cooperate with enterprises, on the one hand, they must obtain related projects, including enterprise logos, cover advertisements, image photography, etc., and then they need to combine course content to complete visual design with students. On the other hand, teachers should guide students to complete market research and related design work independently as much as possible.

\subsection{Craft Studio}

School teachers and the company's technicians (also called "enterprise mentors") usually are jointly responsible for the craft studio of the visual communication major. It usually uses a training base near the school as a studio location. In this way, it can not only make sure that teachers and students complete the specific work of visual design more conveniently, but also organize students to conduct fixed-post internships in accordance with actual demands so as to create external conditions for "double-qualified" teachers and create internal conditions for students to consolidate basic knowledge and improve professional skills.

\subsection{Design Studio}

Usually, professional teachers are responsible for the design studio of the visual communication major. The difference is that such teachers should appear as enterprise designers and manage the studio. At the same time, students have to complete the actual operating tasks of the studio during the learning process. Under normal circumstances, design studios should use the design company as the "design prototype" to allow students to continuously adapt to relevant posts in the form of regular work shift to lay the foundation for them to enter the society in the future.

\section{THE PRACTICE OF "STUDIO SYSTEM" TEACHING MODEL FOR THE VISUAL COMMUNICATION MAJOR IN LOCAL COLLEGES AND UNIVERSITIES}

For local colleges and universities, the formulation and implementation of the "studio system" teaching model for the visual communication major is very important for improving the quality of talent training and innovation. Considering that the "studio system" teaching model of the visual communication major should conform to the development requirements of the times, it not only allows students to have a solid professional foundation and strong practical ability and innovation level, but also ensures that they can adapt to the requirements of the industry, enterprise and market [5]. Therefore, it is necessary to start from improving the quality of employment of students and enhancing the social influence of the school, truly implement teaching and practice through element organization and formation to allow students increase their interest in professional knowledge and practical ability in "learning by teaching and doing by learning", make the overall teaching organization model more flexible and clearer by building a practical teaching system, promote the effective innovation of teaching methods and the significant improvement of teachers' comprehensive ability to meet the needs of students to grow and become talents to the utmost extent through the introduction and distribution of practical training projects, and fully stimulate the inherent potential of teachers and students, comprehensively solve the connection among art, technology, and the market, and improve students' practical ability, market awareness, and comprehensive quality through the formulation and implementation of a long-term incentive system.

\subsection{Element Organization and Formation}

For local colleges and universities, the teaching practice of the "studio system" of the visual communication major requires the joint participation of the school itself, studios, students, teachers, and off-campus enterprises. If circumstances allow, colleges and universities can attract advertising company, industry and company and independent design studio from off-campus enterprises to join the teaching practice. In the meanwhile, colleges and universities should 
provide software and hardware support for the "studio system" of the visual communication major, and supervise, evaluate, coordinate and control the teaching results based on the project results.

\subsection{Building a Practical Teaching System}

The construction of the "studio system" of the visual communication major of local colleges and universities should do more work in terms of functional modules. By building a practical teaching system, the studio should cover all the professional courses of the visual communication major and assume its "own" teaching function. During the period, in the visual design thematic course, it is necessary to recruit famous teachers and industry experts in the industry to a team of part-time instructors to help students consolidate professional knowledge, temper visual design technology, and understand the most cutting-edge industry information. At the same time, young backbone teachers should also be encouraged to conduct in-depth enterprise inspections and further education, and continue to provide "intellectual support" for the "studio" of the visual communication major.

\subsection{Introduction and Distribution of Practical Training Projects}

The practice of the "studio system" teaching model of the visual communication major in local colleges and universities is a complex and systematic project. In addition to the organization and formation of elements and the establishment of a practical teaching system, practical training projects must also be introduced and distributed. On the one hand, it is necessary to continuously expand school-enterprise cooperation to introduce off-campus projects; on the other hand, it is necessary to "reasonably allocate" existing projects, to enable that the visual communication professional training projects can serve both teaching and scientific research, and can also take into account the lower grade undergraduates, the advanced undergraduates and postgraduates, making sure that the project itself always has the characteristics of completeness, systematicness and perspectiveness [6].

\section{CONCLUSION}

In recent years, China's service economy has developed rapidly and the cultural industry has progressed very quickly. The demand for visual communication professionals in the whole society has shown a continuous increase in quantity and quality, which has opened up a very broad market for graduates of this major in advance. At present and for some time in the future, more efforts are needed to continue to address the problems of solid theoretical foundation, lack of practical experience and the obvious gap with market demand in the training of talents in the following aspects: First, it is necessary to continue to optimize the talent training program, ensure that the formulation and implementation of the program is always marketoriented, fully integrate the teacher's knowledge and ability structure, and innovate the teaching design and curriculum system; secondly, the construction and implementation of the "studio system" teaching model for the visual communication major should be as close to the practice, reality and market as possible, so as to prevent the emergence of problems such as being an armchair strategist, and serious disconnection between theory and practice and so on, comprehensively improving students' employment viability and social adaptability; thirdly, it is necessary to update the ideology and knowledge structure of professional teachers in a timely manner, and promote the school's school-running ideas to conform to the development of the times. During the period, it is needed to focus on cultivating students' interest in learning and entrepreneurship and employment, so that the "studio system" teaching model of the visual communication major can continue to achieve actual results to create an open, developing and continuous teaching environment for professional construction and talent training with the joint efforts of teachers, schools, and students.

\section{AUTHORS' CONTRIBUTIONS} Hou.

This paper is independently completed by Jing

\section{REFERENCES}

[1] Suo Li, Li Yingwei. Research on the Teaching Model of the Tutor Studio System for the Visual Communication Art Major [J]. Art Education Research, 2016 (9): 132. (in Chinese)

[2] Xing Lizhi. Feasibility Study on the Combination of Folk Paper-cut Art and Visual Communication Design Professional Teaching 
[J]. Art Science and Technology, 2015(7): 261. (in Chinese)

[3] Dong Lei. Research on the Teaching Model of Visual Communication Design Studio System in Independent Colleges [J]. Modern Decoration (Theory), 2016 (3): 293-294. (in Chinese)

[4] Yang Licheng, Cao Liying, et al. Research on the Cooperation Program of Chinese-foreign Institutes in Local Colleges from the International Perspective - Taking the HIEUHI Program as an Example [J]. Journal of Hunan Institute of Engineering, 2017(2): 8184. (in Chinese)

[5] Zhang Qiang. On the problems and reforms of the teaching and practice of visual communication design major in ordinary colleges and universities [J]. Beauty \& Times (I), 2016 (2): 102-103. (in Chinese)

[6] Zhao Yuhong. Research on the establishment of studio system for visual communication design major [D].Capital Normal University , 2009. (in Chinese) 